\title{
Nilai-Nilai Kearifan Budaya Rumah Joglo (Artefac) Dan Falsafah Kehidupan (Budaya Mantifacts) Pada Komunitas Desa Wisata Pentingsari Sebagai Sumber Pendidikan Karakter Di Sekolah Dasar (SD)
}

\author{
Debi Citra Malahati ${ }^{1}$, Kuspita Sari ${ }^{2}$, Meigy Irma Oktaverina ${ }^{3}$, Ratih Kumalasari 4 \\ 122)344)Program Studi PGSD Universitas Swadaya Gunung Jati Cirebon; Jl. Terusan \\ Pemuda No. 32 , Cirebon; debicitramalahati7@gmail.com, \\ kuspitasari505@gmail.com, meigyirma@gmail.com, \\ kumalasariratih@gmail.com.
}

\begin{abstract}
Abstrak. Penelitian ini bertujuan untuk pelestarian nilai nilai budaya pada kearifan lokal di kota jogyakarta yang berperan dalam pembentukan pendidikan karakter di sekolah dasar. Kearifan lokal merupakan segala bentuk kebijakan yang di dasari oleh nilai- nilai kebaikan yang dipercaya, diterapkan dan senantiasa di jaga keberlangsungannya dalam kurun waktu secara turun temurun oleh sekelompok orang dalam lingkungan tempat tinggalnya. Salah satu contohnya pada kearifan lokal di Jawa yaitu rumah joglo. Rumah joglo merupakan salah satu bangunan arsitektur tradisional yang memiliki kerangka bangunan utama yang terdiri dari soko guru berupa empat tiang utama penyangga struktur bangunan serta tumpang sari yang berupa susunan balok yang disangga oleh soko guru. Sehingga akan berdampak pada pendidikan karakter yang menjunjung tinggi nilai nilai leluhur, bahwsan nya pendidikan karakter merupakan suatu sistem pendidikan yang berupaya menanamkan nilai-nilai luhur. Pengembangan Pendidikan Karakter dan Budaya Bangsa Berwawasan Kearifan Lokal kepada warga sekolah yang meliputi komponen pengetahuan, kesadaran atau kemauan, dan tindakan untuk melaksanakan nilai-nilai tersebut. Hasil ini menunjukan bahwa nilai-nilai kearifan local yang terdapat pada Rumah Joglo yang ada di desa wisata penting sari ini masih kental akan tradisionalnya.
\end{abstract}

Abstract. This study aims to preserve cultural values in local wisdom in the city of Yogyakarta which plays a role in the formation of character education in elementary schools. Local wisdom is any form of policy that is based on the values of goodness that are trusted, applied and always maintained in a period of generations by a group of people in the neighborhood. One example of local wisdom in Java is the joglo house. Joglo house is one of the traditional architectural buildings which has a main building framework consisting of teacher pillars in the form of four main pillars supporting the structure of the building and intercropping in the form of 
blocks arranged by the soko guru. So that it will have an impact on character education that upholds ancestral values, that character education is an educational system that seeks to instill

noble values. Development of Character Knowledge and Nation Culture Education with Local Wisdom to school members which includes the components of knowledge, awareness or willingness, and actions to implement these values. These results indicate that the local wisdom values found in Joglo Houses in this important tourist village of Sari are still traditional.

Kata Kunci. Kearifan lokal, Rumah joglo,Pendidikan karakter

\section{Pendahuluan}

Di indonesia begitu banyak sebuah keragaman kearifan lokalnya namun masih minim dalam pelestarian penanaman nilai- nilai moral leluhurnya sehingga kearifan lokal sangat sulit di lestarikan kepada para generasi . salah satu contoh nya pada kearifan lokal rumah adat. Rumah Adat adalah bangunan yang memiliki ciri khas khusus, digunakan untuk tempat hunian oleh suatu suku bangsa tertentu. Rumah adat merupakan salah satu representasi kebudayaan yang paling tinggi dalam sebuah komunitas suku/masyarakat. Keberadaan rumah adat di Indonesia sangat beragam dan mempunyai arti yang penting dalam perspektif sejarah, warisan, dan kemajuan masyarakat dalam sebuah peradaban. Peneltian ini meneliti salah satu rumah ada yaitu rumah joglo. Rumah joglo merupakan salah satu bangunan arsitektur tradisional di Jawa. Rumah joglo merupakan kerangka bangunan utama yang terdiri dari soko guru berupa empat tiang utama penyangga struktur bangunan serta tumpang sari yang berupa susunan balok yang disangga oleh soko guru. Selain rumah joglo nya penelitian ini meneliti sebuah komunitas pada masyarakatnya dalam pelestarian kearifan lokal yang telah di bangun secara turun temurun . Rumah Joglo pada umumnya hanya dimiliki oleh mereka yang mampu atau kalangan kerajaan, hal ini dikarenakan rumah joglo butuh bahan lebih banyak dan mahal ketimbang rumah bentuk lain. Masyarakat jawa jaman dulu menganggap bahwa rumah joglo tidak boleh dimiliki oleh sembarang orang, tapi hanya diperkenankan bagi kaum bangsawan, raja, dan pangeran, serta mereka yang terhormat dan terpandang. Penelitian ini di buat bertujuan agar para generasi selanjutnya mampu melestarikan penanaman 
nilai nilai leluh pada sebuah budaya kearifan lokal yang dapat di bentuk pada pendidikan karakter di sekolah dasar.

\section{Metode Penelitian}

Dalam penelitian ini, melalui observasi dengan cara dilakukan untuk memperoleh data mengenai "Identifikasi Nilai Kearifan Pada Budaya Artefak Rumah Joglo Desa Wisata Sebagai Sumber Pendidikan Karakter di SD". Pada teknik pengumpulan data yang digunakan dalam penelitian ini dengan cara melakukan observasi, wawancara, dan dokumentasi. Pada Penelitian ini menggunakan observasi langsung dengan melakukan pengamatan dalam rangka mengumpulkan data yang berkaitan dengan masalah penelitian melalui proses pengamatan langsung di lapangan, untuk mendapatkan bukti-bukti yang valid dalam laporan yang akan diajukan, melalui lokasi dan objek penelitian, selain itu penelitian ini menggunakan Tehnik wawancara dengan mengajukan pertanyaan-pertanyaan terstruktur dan menggunakan pedoman wawancara yang disusun secara sistematis serta dapat dikembangkan sesuai dengan situasi dan kondisi di lapangan untuk mengumpulkan data yang dicari.Adapun penelitian ini juga menggunakan mengumpulkan dokumendokumen untuk memperkuat penelitian bisa berupa foto, video, perekam suara, dan media internet serta catatan lapangan.

\section{Hasil Penelitian dan Pembahasan}

Desa Wisata adalah salah satu program dari pemerintah. Pada tahun 2006 pemerintah meluncurkan program yang bernama Pariwisata Inti Rakyat, Pariwisata Inti Rakyat yaitu program pariwisata yang berdasarkan pemberdayaan masyarakat. Desa Wisata Pentingsari dirintis pada awal tahun 2008 sesuai dengan niat dan kesepakatan warga masyarakat setelah melihat dan mengamati beberapa desa wisata lain yang sudah berdiri sebelumnya, kemudian tokoh masyarakat berkumpul untuk membicarakan hal tersebut, semua masyarakat dikumpulkan untuk diajak bermusyawarah dan sosialisasi mengenai rencana Desa Pentingsari akan dijadikan Desa Wisata, dan akhirnya semua masyarakat sepakat. Desa Wisata Pentingsari memiliki ajaran leluhur yang meliputi budi pekerti, sopan santun, dan gotong royong. Gotong royong menjadi hal utama yang sering diterapkan 
dalam kebiasaan hidup sehari-hari masyarakat sekitar, seperti pelaksanaan kenduri/tahlilan, dan nyewu. Ajaran leluhur untuk diwariskan kepada penerus selanjutnya dengan cara mengikut sertakan dalam sebuah kegiatan, dengan diberi pengertian dan arahan untuk bekal di masa yang akan datang. Selain falsafah pada komunitas Desa Wisata Prntingsari adapun beberapa kearifan lokal yang masih terjaga kelestarian nya yaitu Jenis artefak/benda yang dikeramatkan pada masyarakat Desa Wisata Pentingsari mempunyai benda-benda yang di keramatkan seperti kris, batu mulia, dan batu papan. Makna dari benda-benda tersebut sampai di keramatkan karena warisan leluhur kita mempelajari susahnya membuat kris. Cara merawatnya selalu dibersihkan 35 Hari karena ada aturan dan doa nya, ada pintanti, alat pembersihan yang dibersihkan oleh pemiliknya. selain itu Rumah joglo di Desa Wisata Pentingsari pertama didirikan oleh Muah Yuswodiarjo yang merupakan lurah ke- 2 di Desa Pentingsari. Kegunaan rumah joglo di Desa Wisata Pentingsari sebagai aula tempat untuk perkumpulan warga. Pada rumah joglo di Desa Pentingsari terdapat beberapa hiasan yang berfungsi untuk memberi keindahan atau ketentraman dan kesejukan bagi yang menempatinya, hiasan rumah tersebut berupa flora, fauna, dan alam.

Nilai-Nilai Kearifan Budaya Lokal di Desa Wisata Pentingsari, mempunyai jenis artefak/benda yang dikeramatkan pada umumnya masyarakat Desa Wisata Pentingsari mempunyai benda-benda yang di keramatkan seperti kris, batu mulia, dan batu papan. Makna dari benda-benda tersebut sampai di keramatkan karena warisan leluhur kita mempelajari susahnya membuat kris. Cara merawatnya selalu dibersihkan 35 Hari karena ada aturan dan doa nya, ada pintanti, alat pembersihan yang dibersihkan oleh pemiliknya.

\section{Simpulan}

Berdasarkan uraian di atas, dapat diketahui bahwa terdapat makna yang mendalam pada rumah Jawa khususnya Joglo. Rumah joglo dibuat dan direncanakan berdasarkan filosofi yang dianut oleh masyarakatnya, dan dituangkan secara menyeluruh dalam perancangan hunian Jawa berdasar apa yang diyakini. Memahami konsep rumah Jawa berarti memahami bagaimana rumah diartikan oleh masyarakat Jawa, serta nilai-nilai apa saja yang diterapkan dalam wujud fisik yang ada. Namun, seiring perkembangan 
jaman rumah Joglo banyak sekali mengalami perubahan baik dari segi bentuk maupun fungsinya. dapat diketahui bahwa terdapat makna yang mendalam pada rumah Jawa khususnya Joglo. Rumah joglo dibuat dan direncanakan berdasarkan filosofi yang dianut oleh masyarakatnya, dan dituangkan secara menyeluruh dalam perancangan hunian Jawa berdasar apa yang diyakini. Memahami konsep rumah Jawa berarti memahami bagaimana rumah diartikan oleh masyarakat Jawa, serta nilai-nilai apa saja yang diterapkan dalam wujud fisik yang ada. Namun, seiring perkembangan jaman rumah Joglo banyak sekali mengalami perubahan baik dari segi bentuk maupun fungsinya.

\section{Daftar Pustaka}

Judiani, S., (2010). Implementasi pendidikan Karakter di Sekolah Dasar Melalui Penguatan Pelaksanaan Kurikulum. Jurnal Pendidikan dan Kebudayaan. 16, 281-283.

Sagrim, H., (2010). Evolusi Arsitektur. Arsitektur Tradisional Jawa dalam Perkembangan Sosial Budaya Modern.

Sularso. (2016). Revitalisasi Kearifan Lokal dalam Pendidikan Dasar Revitalization of Local Wisdom in Education. Jurnal Pendidikan Sekolah Dasar. 2(1), 77-78.

Suyitno, I., (2012). Pengembangan Pendidikan Karakter dan Budaya Bangsa Berwawasan Kearifan Lokal. Jurnal Pendidikan Karakter. 3-5. 